\title{
Designing and Developing a Gis Database For Tourism In Nigeria: The Case Of Anambra State
}

\author{
Akukwe, Thecla I. ${ }^{1}$ and Odum, Chigozie, J. ${ }^{2}$ \\ ${ }^{I}$ Department of Geography, University of Nigeria, Nsukka, Enugu State \\ ${ }^{2}$ Department of Geography and Regional Planning, University of Calabar, Cross River State
}

\begin{abstract}
Tourism has been noted to be one of the important sectors of the Nigerian economy. Tourism is a highly complex activity which requires tools that aid in an effective decision-making to come to terms with the competing economic, social and environmental demands of sustainable development. Geographic Information System (GIS) is one of such tools. GIS being an information system that is capable of answering questions about where facilities and resources are located represents enormous benefits to the tourism sector of any economy. The power of GIS lies not only in the ability to visualize spatial relationships, but also beyond the space to the holistic view of the world with its many interconnected components and complex relationships. The use of GIS technology could assist the Anambra State government as well as the Nigerian government with better planning of tourism infrastructure, location and dissemination of such infrastructure, production of better quality maps showing tourists sites etc because of the dynamic capability of GIS tools to incorporate changes that occur over time to its database. A GIS database for tourism in Anambra State was created using some selected roads, tourist attractions and facilities with the aid of base maps and GPS. This paper presents the significant role that GIS can play in tourism development in Anambra State if a complete database for tourism in the State is designed and developed.
\end{abstract}

Keywords: GIS, Tourism, Anambra, Nigeria

\section{Introduction}

Tourism is one of the major sources of income in the world today and an important export industry and chief of foreign exchange in many countries like United States of America (U.SA.), United Kingdom (UK), Germany, China, and Austria while African countries like Kenya and Zimbabwe have approximately 80\% tourists coming into their countries primarily for wildlife (Graham-Douglas, 2008). International tourist arrivals reached a record of 982 million, an increase of $4.6 \%$ in 2010 , while receipts grew by $3.8 \%$ to US $\$ 1.030$ billion (£740bn) (UNWTO, 2011). Tourism is now the greener pastures most developing countries have focused attention to due to its enormous benefits like infrastructural development, job creation, conservation of environment etc (Okonkwo and Odum, 2010). In Nigeria, it is an important sector that has not fully developed, though; it is one of the country's fastest growing industries (Oladipo, 2010). Recently, it is contributing about $3 \%$ of Nigeria GDP (Nigeria Tourism Master

Plan, 2006).

Tourism has historically been dependent on the character of the destination, including attractions, beaches and resorts. It is a complex activity that requires the availability of certain parameters (e.g. accessible road networks, standard accommodation facilities, attractions etc) and information on potential and existing attraction sites. Information on these parameters and attraction sites can be gathered, processed, organized and stored using tools such as Global Positioning System (GPS), Geographic Information System (GIS) coupled with remote sensing. After gathering the needed data about a destination, the data must be stored in a retrievable form to enhance tourism, and this can be achieved with the aid of GIS.

Geographic Information Systems (GIS) is one of the most remarkable technologic innovations in tourism planning and decision making. "Both GIS and tourism share a common characteristic, that is, both cross the boundaries of disciplines and application areas. GIS has been applied in many fields including geography, forestry, urban development and planning, and environmental studies. Similarly, tourism has been a subject of interest to geographers, economists, business, environmental planners, anthropologists, and archeologists" (Avdimiotis and Christou, 2002:1). This makes the potential applications of GIS in tourism significant.

Moreover, maps have been known to play vital roles in identifying and locating tourist attractions. GIS however provides the facility to extract different sets of information (e.g. tourist attractions, hotels and their distances from one another, roads, settlements, vegetation, land use data, changes in tourism resources) from a map and use them as required (Fajuyigbe, Balogun and Obembe, 2007) because of the dynamic capability of GIS tools to incorporate changes that occur over time to its database (see Table 1). 
Tourist maps in Nigeria are not easily seen or available, where available it is lacking in comprehension, accuracy and up-to date georeferencing (Olabintan and Ajirotutu, 2012). This paper presents the practical use of GIS to process, organise, store and disseminate already captured data on tourist attraction sites to enhance tourism development in Nigeria with special emphasis on Anambra State where few attractions were mapped and used in preparing a thematic layer.

Table 1: Capabilities of a GIS

\begin{tabular}{|c|c|c|}
\hline $\begin{array}{l}\text { Functional capabilities } \\
\text { of a GIS }\end{array}$ & GIS Basic Questions & Tourism Applications \\
\hline $\begin{array}{l}\text { 1. Data entry, storage and } \\
\text { manipulation }\end{array}$ & 1.Location 1. What is at? & 1. Tourism Resource Inventories \\
\hline 2. Map production & $\begin{array}{l}\text { 2. Where is it? } \\
\text { 2.Condition }\end{array}$ & $\begin{array}{l}\text { 2. Identify most suitable locations for } \\
\text { development }\end{array}$ \\
\hline $\begin{array}{l}\text { 3. Database integration } \\
\text { and management }\end{array}$ & 3.Trend 3 . What has changed? & 3. Measure tourism impacts \\
\hline $\begin{array}{l}\text { 4. Data queries and } \\
\text { searches }\end{array}$ & 4. Which is the best route? & 4. Visitor management/flows \\
\hline 5. Spatial analysis & 5. What is the pattern? & $\begin{array}{l}\text { 5. Analyze relationships } \\
\text { associated with resource use }\end{array}$ \\
\hline $\begin{array}{l}\text { 6. Spatial modelling } \\
\text { 7. Decision support }\end{array}$ & 6.Modelling & $\begin{array}{l}\text { 6. Assess potential impacts of tourism } \\
\text { development }\end{array}$ \\
\hline
\end{tabular}

Source: Bahaire and Elliot-White 1999, p. 159 (cited in Avdimiotis and Christou, 2002:2)

\subsection{Definition Of Terms What is GIS?}

GIS is a computer based set of tools for collecting, mapping, analyzing, storing, retrieving, and displaying spatial and non spatial data from geographic world for a particular set of purposes that varies from one discipline to another. It is a computer software that links geographic information (where things are) with descriptive information (what things are).Unlike a flat paper map, where what you see is what you get, GIS can present many layer of different information (www.esri.com). GIS is both a database system with specific capabilities for spatially referenced data as well as a set of operations for working (analysis) with the data (Wheatley et al. 2002). It is also a set of computerized tools used to collect, archive, manage, retrieve, analyze and output geographic and other related kinds of attribute data (Chikwanda 2004).

According to Fellaman et al (2008) GIS is "both an integrated software package for handling, processing, and analyzing geographical data and a computer database in which any piece of information is attributed to a precise geographic location. They further explained that a GIS database can be seen as a set of discrete informational overlays lined by reference to a basic locational grid of latitude and longitude.

\section{What is Tourism?}

World Tourism Organisation (1995) has defined tourism as "the movement of people to and stay in places outside their usual home for at least twenty-four hours but not more than one consecutive year for leisure, business and other purposes not related to any form of employment from within the place visited." It is the temporary movement of people to destinations outside their normal places of work and residence, the activities undertaken during their stay in those destinations and facilities created to cater to their needs (Cook et al, 2006). Tourism is the movement of person(s) (tourist(s) from one socio-cultural background to another with the main intention of engaging in recreation and adventure. There are two main types of tourism namely domestic tourism (residents of a country travelling within their country. A Nigeria from Sokoto travels to Obudu Cattle Ranch in Calabar) and international tourism connotes nationals of a country travelling to another country for instance Nigerians travelling to Spain.

Looking for a comprehensive definition of tourism is elusive, because the definition is marred with a lot of bias, each definition is given based on the authors level of biasness and each generation and epoch defines it based on its usefulness and perception while the interdisciplinary nature of the concept makes the definition more complex (Marguba, 2001 and Odum 2011). Any attempt to define tourism is an all but impossible task (Holloway, 2006). Although Okpoko et al (2008) succinctly identified five notable characteristics of most tourism definitions namely:

(i) tourism arises from the movement of people to and stay in various destinations as

well as their activities therein (ii) that the journey to and the stay take place outside

one's normal place of residence and work (iii) that the movement must not be less 
than twenty-four hours and not more than one year. Any movement away from home that is less than 24 hours is referred to as excursion (iv) that the movement to other destination is temporary and short-term, with the intention of returning home within a few days, weeks or months (v) that the money spent during such travel and stay is derived from home and not earned in the destination.

There are various kinds/forms of tourism namely: cultural tourism, religious tourism, business tourism, sports tourism, ecotourism, humane tourism, responsible tourism etc.

Tourism is an activity highly depended on environmental resources. It is also a phenomenon, which in the event of lack of proper planning and management is likely to erode its environmental base, hence, the strength of tourism planning and decision making can be enhanced with GIS applications, which provide a toolbox of techniques and technologies of different applications to the achievement of sustainable tourism planning development.

Tourism cannot thrive without accurate and reliable information about a destination as listed in table 3 (appendix) which will be the main element that will draw tourists/visitors. A tourist/visitor cannot visit a destination he/she has little or no knowledge about. Therefore, there are a whole lot of questions to ask about tourism data e.g. what kinds of tourist attractions are there in a place and their locations? Where are tourists coming from? What attraction do they visit most? What time of the year do they normally come? What types of hotels are in the destinations? The distance between hotels and attractions, is the attractions developed like having lodging and restaurants facilities, etc? All these questions can be gathered, uploaded with the aid of GIS and can be accessed by tourists and updated by tourism planners. Table 2 shows some tourism related issues and GIS applications.

Table 2: Common tourism-related issues and GIS applications

\begin{tabular}{|l|l|}
\hline Problems & GIS Application \\
\hline Benchmark/database & Systematic inventory of tourism resources \\
\hline Environmental management & Facilitating monitoring of specific indicators \\
\hline Conflicts & Mapping recreational conflicts: recreation-wildlife; user conflict \\
\hline Tourism behavior & Wilderness perceptions \\
\hline Carrying capacity & Identify suitable locations for tourism/recreation development \\
\hline Prediction & Simulating and modeling spatial outcomes of proposed tourism development \\
\hline Data integration & $\begin{array}{l}\text { Integrating socio-economic and environmental datasets within a given spatial } \\
\text { unit }\end{array}$ \\
\hline Development control and direction & Decision support systems \\
\hline
\end{tabular}

Source: Adapted from Butler 1993:33 (cited in Bahaire and Elliott-White 1999:162 and

cited in Avdimiotis and Christou, 2002:3).

\section{Literature Review}

The use of GIS in tourism studies has being minimal though GIS technology has been in tourism related literature over the years (Gunn and Larsen, 1988). Some scholars are of the view that its application has been limited to recreational facility inventory; visitor impact assessment; tourism-based land management, recreation- wildlife conflicts, mapping wilderness perceptions (Nedovic-Budic et al 1999; Feick and Hall, 2000; Nepal, 1999; Caver, 1995 in Wayne, 2003).

GIS has been applied in designing and development of tourism destinations in Zlatibor (Cajetina) and Zlatar (Novavaros) areas of Serbia (Jovanovic and Ngegus, 2008); while Avdimiotis and Christous (2002) used GIS to establish or measure the carrying capacities of the Muncipality of Chalkidiki, Greece. According to them the carrying capacity can be defined as the maximum number of tourists that can be accommodated in a specific area (place of reception) of tourists) without causing any desirable alteration in the natural-economic and social environment of the host community. Seker et al (2002) applied GIS to support planning activities for tourism in the Manavgat region located in southern coast of Turkey, and focused on the analysis, decision making and management using GIS technique.

In Nigeria, Fadahunsi (2010) portrayed the importance of GIS and tourism management using it to create awareness of the existence of the tourist attraction centres to the prospective visitors in Osun State. In a related study, Omitogun and Oyinloye (2008) worked on Osogbo grove in Osun State with the aid of remote sensing and GIS in order to get the sacred grove registered on the World Tourist Map. Similarly, Ayeni (2006) developed a user-friendly Multimedia GIS database which constitutes a great resource for producing various tourist maps of Nigeria and for educational institutions offering courses in tourism in Nigeria. Fajuyigbe et al (2007) developed a web-based Geographical Information System (GIS) for Tourism in Oyo State, Nigeria and 
their project revealed that presenting tourism information in GIS in a computer environment and the internet would offer an unparallel platform for the management and promotion of the tourism industry in Oyo State.

Though, the integration of tourism data and GIS data is still a big challenge for the tourism industry today, it was observed from the reviewed literatures that using GIS always keeps the information up to date, reduces cost and saves time, provides information for decision support and policy making, increases efficiency in tourism activities, increases management control etc (Avdimiotis and Christous, 2002; Seker et al 2002; Ayeni, 2006; Fajuyigbe et al 2007; Fadahunsi, 2010). The advantages of GIS in tourism as identified above, informed the choice of this research which sought to design and develop a GIS database for tourism using spatial and attribute data in Anambra State as this has not been done for the State.

\section{Study Area}

Nigeria is located within Latitudes $4^{\circ}$ and $14^{\circ} \mathrm{N}$, and Longitudes $3^{\circ}$ and $15^{\circ} \mathrm{E}$. It is bordered by the Republic of Benin in the west, Chad and Cameroon in the east, Lake Chad in the northeast, Niger in the north and has a coast that lies on the Gulf of Guinea in the south. Nigeria has a land area of $910770 \mathrm{Sq} . \mathrm{Km}$. Some notable geographical features in Nigeria include the Mambilla Plateau, Biu plateau, Adamawa highlands, , Jos Plateau, Obudu Plateau, the Niger River, River Benue and Niger Delta.

Etymologically, Anambra derived its name from Omambala River which is easily called Anambra River. Omambala River is on the Northern part of Anambra State and stretches to the famous River Niger (Anambra State Diary 1994 in Odum 2011). The indigenous ethnic groups in Anambra state are the Igbo (98\% of population) and a small population of Igala ( $2 \%$ of the population) who live in the North western part of the state (http://en.wikipedia.org/wiki/Anambra_State).

Anambra State is geographically located in the southeastern Nigeria, and it is bounded by Delta State to the West, Imo State to the South, Enugu State to the East and Kogi to the North. It is located between Latitude $5^{\circ} 41.293^{\prime} \mathrm{N}$ and Latitude $6^{\circ} 46.327^{\prime} \mathrm{N}$, and Longitude $6^{\circ} 37.014^{\prime} \mathrm{E}$ and Longitude $7^{\circ} 21.608^{\prime} \mathrm{E}$. It has one of the highest population's densities in Africa. The State comprises numerous thickly populated villages, a number of small towns and a few major towns; some areas are so thickly populated that the estimated density is 1500-2000 persons living within every square kilometer (www.anambrastate.org). In 2006, the population was estimated to $4,182,032$, while the density remains 863/km in 2006 (Anambra State Government Pamphlet 2008 in Odum 2011) with a total land area of $4,844 \mathrm{~km}^{2}(1,870 \mathrm{sq} \mathrm{mi}$ ) (www.anambrastate.org).

\section{Methodology}

Tourism attractions in Nigeria data were classified into four types viz; Natural, Historic, Man-made and Cultural attractions (see appendix for the list of tourism attractions in Anambra State and Nigeria).

\subsection{Creating GIS database for tourist attraction sites}

GIS makes use of two data elements spatial and attribute data. Spatial data is referred to as a known location (established longitude and latitude coordinates) on the surface of the Earth. The spatial data elements comprises of using of exact standard geographical frame of reference such as latitude and longitude, and using surrogates spatial references like postcode while the attribute data show statistical and non-location data (e.g. images, texts) associated with a spatial entity (Jovanovic and Njegus, 2008:263). The Database for these tourism (attractions) data was created using the co-ordinates of their geographical locations in their various States in Nigeria. The spatial data were developed using Google Earth (web mapping application) and ArcGIS 10.0 software.

\subsection{Methods of data acquisition}

Two methods were employed viz; primary and secondary.

4.2.1 Primary data: the co-ordinates of the sampled attractions and some tourism facilities in Anambra State were collected by ground truthing with GPS.

4.2.2 Secondary data: these were collected through journals and literatures e.g. the list of attractions and the States where they are located.

\subsection{Procedure for the development of the GIS database}

- Trace the 36 States of Nigeria and roads (Keyhole Markup Language (KML) shape files) on Google Earth which are already geo-referenced. These formed the base maps. Keyhole Markup Language (KML) is the primary mechanism supported by Google for interchanging GIS data, maps, and graphics information in the Google Earth and Google Maps communities. In addition, map services published using ArcGIS Server can be served using KML. Dynamic KML content is retrieved each time the map service is accessed from ArcGIS Server. This enables up-to-date KML content to be served for dynamic GIS content. 
- Import these KML polygons and paths (shape files) into ArcGIS 10.0 and convert them to layers using the Conversion Tools in ArcToolbox.

- Create another shape file (points) to locate the various attractions.

- Merge the different polygon (e.g. States shape files) into one layer using the ArcToolbox in Arcmap (See Fig.1).

- Create relationships and queries among the features (See Fig.1 and 2). E.g. The Analysis (Proximity) tools in the ArcToolbox can be used to calculate the nearest distances from one attraction to another.

The procedure above was followed to produce Fig.2, a thematic map layer showing selected hotels and tourist attraction sites in Anambra State. With data on tourism facilities like the road network, hotels, flora and fauna inventory, modes of transport, locations of airports, banks and parks, towns in Anambra State, Nigeria etc, tourists and the public can get answers to certain questions (e.g. the distance to different towns, the nearest hotel) by making queries once linked to a webpage (using the hyperlink tool on the GIS software).

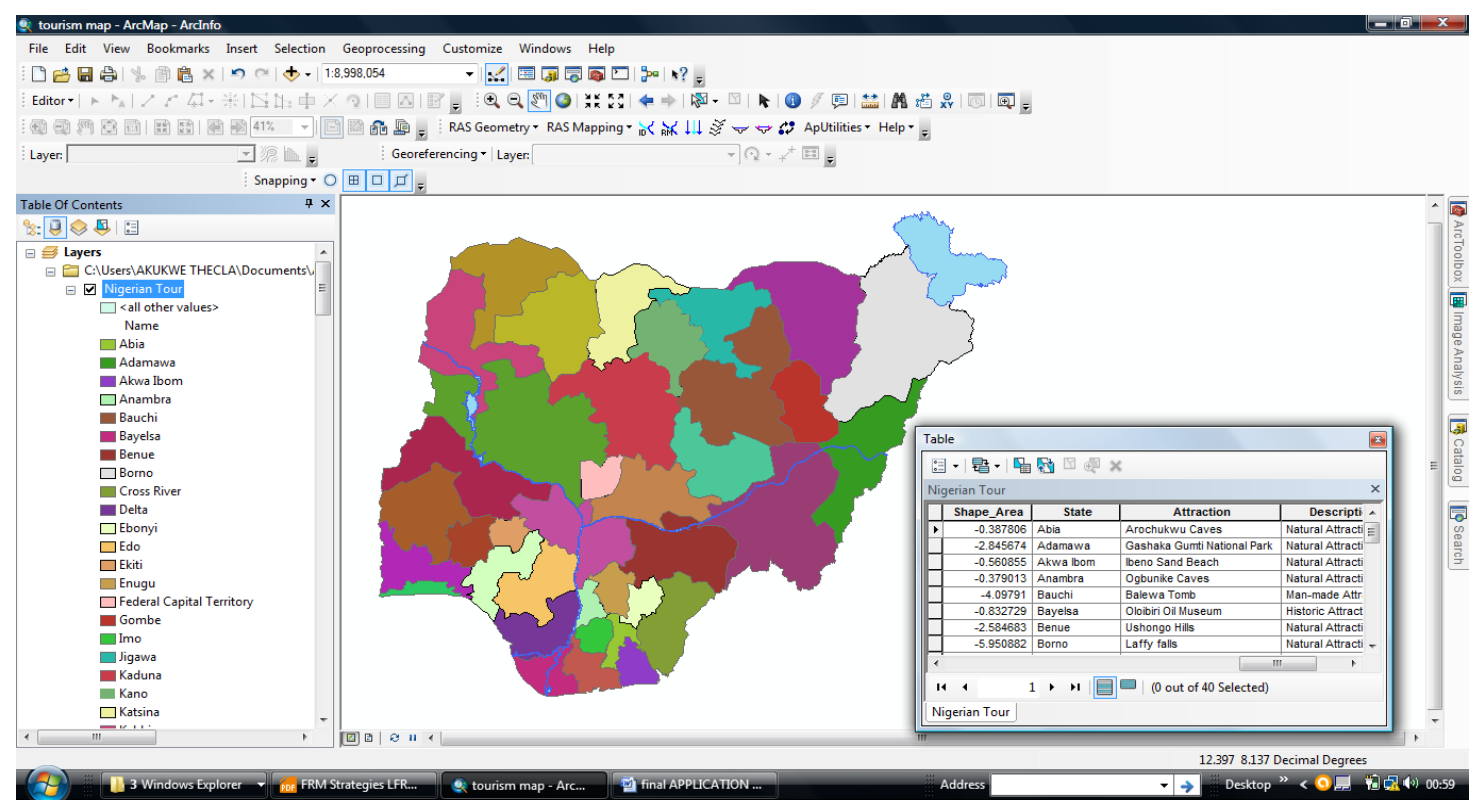

Fig.1: Map of Nigeria showing the 36 States where tourism attractions are located Note the attribute table in the figure.

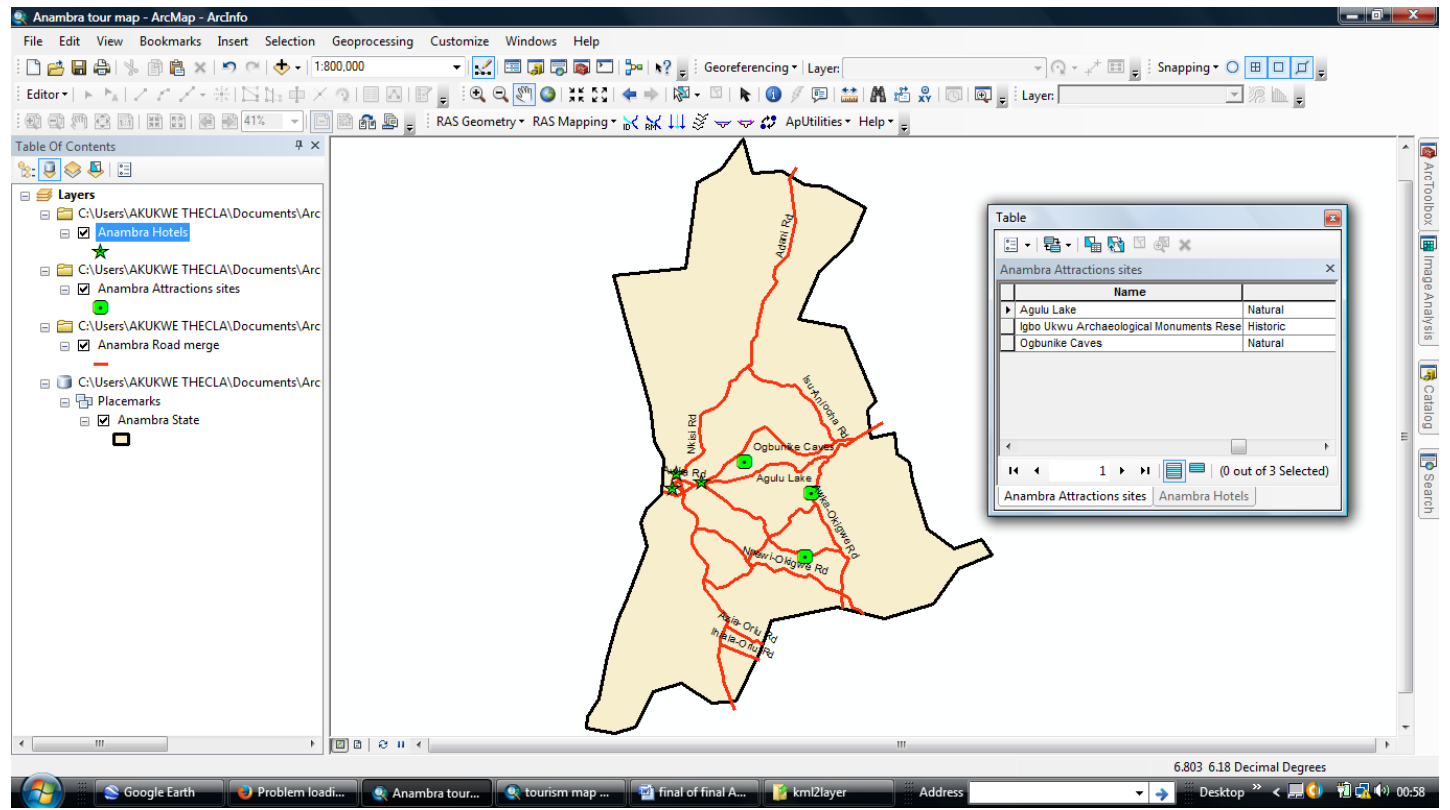

Fig.2: Map of Anambra State showing major roads and some tourism attractions. 


\subsection{The Role of GIS in Tourism}

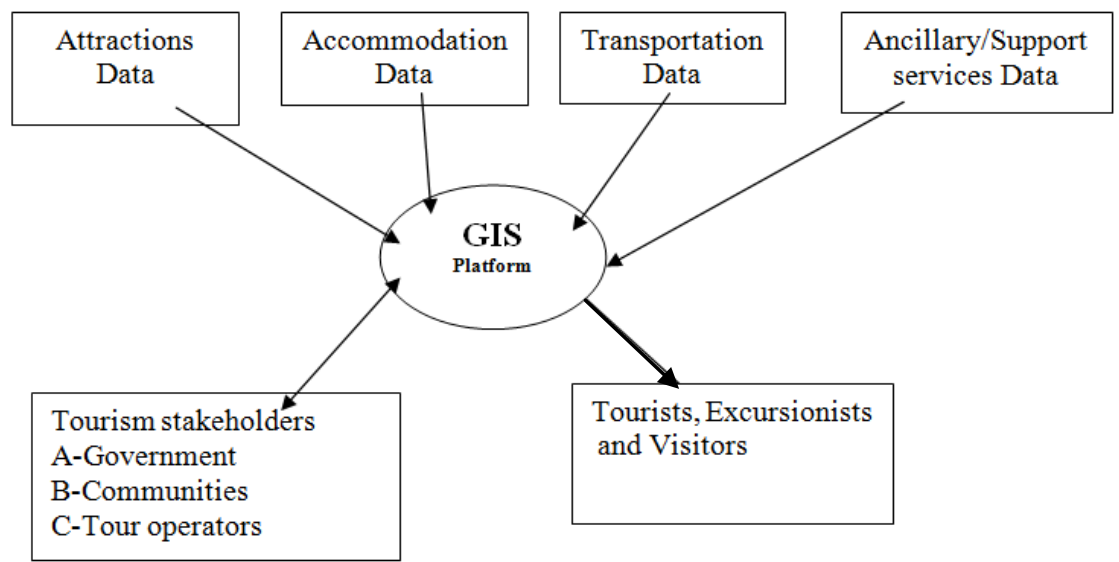

Fig.3: A proposed Tourism-GIS model of communication

\section{Importance of GIS Application In Tourism}

GIS in tourism is advantageous to both tourists and for the tourism development authorities. These advantages are outlined below;

\section{GIS gives detailed and enriched information about a tourist destination}

A GIS database would give intending tourist enlightenment and enriched information of his/her destination of choice as well as the various cultural and natural attractions therein. Moreover GIS data/information will assist tourist in making comparative analysis to know areas to visit. This is possible once the GIS database (showing tourism attractions and facilities) is linked to the Anambra State website.

\section{GIS Applications helps in Tourism Planning and Decision Making Process}

Tourism development is a complex phenomenon, because stakeholders have to face challenges like other competitive economic, social and environmental requirements of sustainable development. Environmental exploration, impact assessments and simulation are vital to tourism development, and GIS can assist in auditing environmental conditions, assess the suitability of an area/location for any proposed tourism development, taking cognizance of conflicting interests and modelling relationships (Bahaire and Elliot-white, 1999:159). GIS gives room for comparative study of land use options and other environmental resources e.g. there are areas that might have a good attraction but it may not be developed rather will be more useful in other activities like agriculture or industrial sites. A complete GIS database will help Anambra State Authority weigh their options of either investing in tourism or other alternatives like farming.

\section{Creation of Inventory and data base for tourism experts, tourists and different stakeholders}

GIS application helps in performing numerous tasks in tourism planning and development. First is creating resource inventory, area designation and map overlay, comparative land use and impact analysis, community participation, data integration and management etc. Its application can provide different types of information and maps which can be of enormous benefits to Nigeria Tourism Development Co-operation (NTDC), travel agencies, tour operators in Nigeria for easy planning and allocation of resources.

\section{Monitoring of trends, events and movements and adaptive to change}

During festival periods like fishing festivals, Dubar, boat regatta, New Yam festival, the popular Calabar festival etc. Tourism planners and Nigeria Tourism Development Co-operations (NTDC) can use GIS technology to monitor such big events. This will assist in the area of indicating the population size, the pattern of movements, and impacts of tourists on the environment. Once a GIS database has been created, it can be updated easily by adding new features to already existing ones. For example, trend analysis can be done using GIS tools to monitor changes over the years. GIS can provide a set of tools, which can be used for tourism planning and development. Also, GIS tools can equally be employed to monitor the movement of animals in game reserves and National parks, especially animals that are going into extinction. Similarly, the trend of cultural festivals (e.g. New Yam festivals, Ofala Festival, Mmanwu) in Anambra State can be monitored and analyse with using GIS. 


\section{Internet Advantage/ Reduction in fraud}

GIS application over internet (web-based GIS) is a landmark technological development in tourism planning and policy making. The internet has opened new ways of computer related communications, giving room for new methods of information circulation, group working, social interaction/chatting, and easy integration of models and samples of ideas. The multimedia ability of the web has made it a medium for visual representations like graphs and diagrams of different forms, maps, and images are now easy to implement as text (Avdimiotis and Christou, 2002). With the adaptability and capability of GIS on the internet, tourists can confirm geographical information with tour operators on line and access other vital information. This will help to reduce fraudster who usually place none existing destination in other defraud unsuspecting tourists.

\section{Challenges Of GIS in Tourism in Nigeria}

- Human resource - tourism development and practice is still relatively new in this part of the world, while government is yet to pay adequate attention needed to develop the sector. The number of tertiary institution offering tourism and GIS courses is still low. This creates a big gap in creating the man power needed to drive the industry. Similarly, GIS training in Nigeria is still very low due to lack of expertise and the newness of the technology in the country.

- Non acceptance of technological advancement/ ignorance of the current trends of events - some Nigerians are sluggish in changing from the traditional/primitive ways of data collection and analysis; they still prefer the manual method of using their drawing boards, pens, tracing sheets, makers, T-square etc. While some prefer their analogue method where data are acquired and store in boxes in the office and manually retrieved when the need arises, some are of ignorant of the current trends of events (the use of GIS technology). Most tourism units and departments in Nigeria, still prefer manual/traditional method of data collection especially in the area of inventory probably due to the financial gains as a result of going to site (duty allowances) than learning the GIS and that is easy and fast; giving answers in seconds and minutes.

- Expensive nature of GIS Laboratory- a complete GIS laboratory requires some expensive equipment and software (including remote sensing tools). The Nigeria SAT-1 that was launched in September, 2003 cost Nigerian government a whooping sum of $\$ 13 \mathrm{~m}$. The cost of acquiring GIS components and software is equally expensive. Since Department of Tourism is still under Ministry of Information and Culture in Anambra State, it is difficult to convince the State on the imperativeness of GIS technology.

- Poor public awareness- the knowledge, benefits and functions of GIS is not known beyond tertiary institutions that offer GIS as a course of study. Fadahunsi (2010) added that "many see GIS as a "beyondthe-reach" technology, while some mystify it; this has kept many from grasping the immense opportunity and power it gives especially in decision making". Therefore, one may ask, how many tourism departments, ministry and parastatal have the knowledge of this GIS?

\section{Recommendations}

There is urgent need to critically look into potentials of application of GIS in the tourism industry of Anambra state and Nigeria at large. Other countries of the world and multinationals are benefitting from this technology. Example, Hertz Corporation is using the technologies of geographic information systems, global positioning satellites (GPS), and electronic route guidance software in its Hertz NeverLost ${ }^{\mathrm{sm}}$ system. When a traveler picks up a Hertz NeverLost ${ }^{\mathrm{sm}}$ equipped rental car, he or she can punch in the address of a hotel and receive computer-generated voice instructions and video display of the directions (Cook et al, 2006).

Institutions of higher learning are to take the lead in the integration of GIS into various courses with special interest in archaeology (including geography) and tourism studies with the aim of making tourism in Nigeria meet up with international standards (Olukole, 2007). It will also equip Nigerian graduates to compete favorably with their peers all over the world, and we equally advocate for establishment of GIS centers in all the thirty-six States of the federation.

It is highly recommended that the application of GIS in tourism in Nigeria should be diversified (it should involve other attractions like the National parks, Game reserve, protected areas, caves, waterfalls etc). It should not be on only cultural attractions and this will help to re-direct the tourist pressure on these cultural tourism (especially fishing festivals, Calabar carnival, and Abuja carnival, New yam festival) areas to avoid exceeding some destination's carrying capacity which will lead to environmental degradation.

\section{Conclusion}

Tourism has been noted as one of the world's largest, fast and rapid growing sector with a contribution of $10 \%$ to global GDP, creating employment for 200 million people. The importance of GIS to tourism cannot be overemphasized. It is beneficial to both tourist operators and tourists themselves. Its ability to add changes in an existing destination makes it appealing to marketers while changes brought by tourist activities/tourism 
related activities can be monitored with GIS thereby ensuring sustainability because such changes can be monitored and remedied if it is detrimental. GIS being an information system that is capable of answering questions about where facilities and resources are located presents enormous benefits. Until recently, the use of GIS in Nigeria has been limited to oil fields, hydroelectric power, national forest and agriculture among others at the expense of other projects like tourism and archaeological projects. NTDC is yet to make good use of such facility. This is seen in the dearth of a comprehensive and detailed map of tourist attractions in the country.

Anambra State is one of the States in the Eastern Region with numerous tourist attractions yawning for development. GIS is a vital tool that can be explored by the State to develop its tourism potentials and expand its tourism market. It gives accurate location of distances between one attraction to the other, road networks, hotels, distance between hotels and attractions etc. If a tourist is armed with detailed information about a destination it might increase his/her appeal to such a destination. A look at Fig.2 shows a GIS platform with few tourism attractions and hotels in the State which a tourist can use to know what is obtainable and other attributes of his destination.

Therefore, the application of GIS in tourism is recommended because of the easiness and fastness in identifying tourist sites and attractions with accompanied details so that Nigeria will have a comprehensive map of what they have in each State, Local Government Area and Town.

\section{References}

[1]. Avdimiotis Spyros and Christou Evangelos (2002) G.I.S Applications In Tourism Planning "A Tool For Sustainable Development Involving Local Communities". Available online at http://www.un.org/esa/agenda21/natlinfo/wssd/greece.pdf United Nations 2002 Country Profiles Series. Retrieved on 19 April, 2013.

[2]. Ayeni, O.O. (2006). A Multimedia GIS Database for Planning Management and Promotion of Sustainable Tourism Industry in Nigeria. TS 72 - GIS Application to Planning Issues. Shaping the Changes. XXXIII FIG Congress, Munich, Germany, 8-13, 2006

[3]. Bahaire, T. \& Elliott-White, M. (1999). The application of Geographical Information Systems (GIS) in sustainable tourism planning: A review. International Journal of Sustainable Tourism, 7 (2), 159-174.

[4]. Beeton Sue (2006) Community Development through Tourism. Australia: Landlinks Press.

[5]. Chikwanda, G. (2004) A GIS approach in the documentation of dry stone walled heritage sites - a conservation and management tool. Unpublished paper presented to STOCON's 10th International Congress on Deterioration and Conservation of Stone in Sweden.

[6]. Cook Roy. A, Yale Laura J. and Marqua Joseph J. (2006). Tourism: The Business of Travel. New Jersey: Pearson Education. Inc.

[7]. Fadahunsi, J.T. (2010) "A Perspective View on the Development and Application of Geographical Information System (GIS) in Nigeria. Pacific Journal of Science and Technology. 11(1):301-308.

[8]. Fellmann J.D, Bjelland Mark D.,Getis Arthur and Getis Judith (2008) Human Geography: Landscapes of Human Activities. New York: McGraw-Hill.

[9]. Graham-Douglas Tonye Alabo (2008) "Welcome Address by the Honourable Minister of Culture and Tourism". In Aremu A. David (ed.) Preservation of Land Culture and Wildlife for the Development of Ecotourism in Africa. Ibadan: Spectrum Books Limited.

[10]. Gunn, C.A, and Larsen, Terry R. (1998) Tourism Potential-Aided by Computer Cartography. Aix-en-provence, France: Centres des Hantes Etudes Touristiques.

[11]. Holloway Chris (2006) The Business of Tourism. England. http://www.esri.com/ /media/c371 f47805c345fa84d32ac8a675046e.pdf Accessed on 30th April, 2013.

[12]. Jovanovic Verka and Njegus Angelina (2008) “The Application of GIS and Its Components in Tourism. Yugoslav Journal of Operations Research. Vol. 18(2):261-272.

[13]. Fajuyigbe, O., Balogun, V.F. and Obembe, O.M. (2007). Web-Based Geographical Information System (GIS) for Tourism in Oyo State, Nigeria. Information Technology Journal, 6:613-622.DOI:10.3923/itj.2007.613.622 URL: http://scialert.net/abstract/?doi=itj.2007.613.622

[14]. Malczewski, J. (1999). A GIS-based approach to multiple criteria group decision-making. International Journal of Geographical Information Systems, 13 (8), 955-968.

[15]. Marguba L.B. (2001) “A keynote address on "The Relevance of Tourism (Cultural and Eco-tourism) in Nigeria Towards Our 21 Century National Economic Development.” In Aremu A. David (ed.) Cultural and Ecotourism Development in Nigeria: The Role of Three Tiers of Government and the Private Sector. Ibadan: Hope Publications.

[16]. Nigeria Tourism Master Plan (2006) Nigeria Tourism Master Plan: Institutional Capacity Strengthening to the Tourism Sector in Nigeria. NIR/03/002.

[17]. Odum C. J. (2011) Community involvement in Tourism Planning and Development: A study of selected Tourism Attractions in Anambra State. An M.A project submitted in Department of Archaeology and Tourism, University of Nigeria, Nsukka.

[18]. Okonkwo E.E. and Odum C.J (2010) "Tourism an Alternative for Economic Independence and Rural Development in Nigeria". (ed.) Nekang, F.M Africa Journal of Pure and Applied Science..Vol.5.No.3.

[19]. Okpoko P.U., Okonkwo E.E. \& Dimiyi C. (2008) Understanding Tourism. Nsukka: University of Nigeria Press Ltd.

[20]. Omitogun A.A and Oyinloye R.O. (2008) Remote Sensing and GIS for Tourism Development: An Experience with Osogbo Grove Osun State, Nigeria.

[21]. Olabintan D.D and Ajirotutu, J.O, (2012) "Application of Geographic Information System (GIS) in Tourism Mapping for Sustainable Tourism Development in Owo Local Government Area (LGA), Ondo State, Nigeria”. Paper Presented on $4^{\text {th }}$ International Conference on Educational and New Learning Technologies. Barcelona, Spain. Available on line at www.library.iated.org/view/OLABINTAN2012APP. Retrieved on 29th of April, 2013.

[22]. Oladipo, E. (2010) Towards enhancing the adaptive capacity of Nigeria: a review of the country's state of preparedness for climate change. A report submitted to Heinrich Boll Foundation, Nigeria in September 2010.

[23]. Olonade T. O (2000) An Archaeological Study of Landuse Change and Prediction of Archaeological Site of Ijaiye Orile using GISAid. An undergraduate project, Department of Archaeology and Anthropology, University of Ibadan. 
[24]. Olukole Titilayo O. (2007) Geographical Information System (GIS) and Tourism: The Prediction of archaeological sites in IjaiyeOrile, Southwestern Nigeria. Available online at http://safa.rice.edu/Nyame-Akuma/NA-066-070/Nyame-Akuma-Issue-067olukole. Retrieved on 19 April,2013.

[25]. Pearce, D. G. (2000). Tourism plan reviews: Methodological considerations and issues from Samoa. Tourism Management, 21 (2), 191-203.

[26]. Seker, D.Z., Kabdasli, S., Duran, E., Mercan, D.E. and Elginoz, N. (2002). Analyzing and Management of Tourism activities by means of GIS Technique. International Symposium on GIS, September 23-26, 2002, Istanbul Turkey.

[27]. UNWTO (2011) World Tourism Organisation Annual Report. Spain: Madrid.

[28]. Wayne Giles (2008) GIS Application in Tourism Planning.

[29]. Wheatley, David and Gillings, Mark (2002) Spatial Technology and Archaeology. The Archaeological Application of GIS. London, New York, Taylor \& Francis.

[30]. World Tourism Organization (1995) UNTO Technical Manual: Collection of Tourism Expenditure Statistics.

[31]. www.ehow.co.uk/info-8294848-gis-applicants-tourism.html. Retrieved on $25^{\text {th }}$ April, 2013.

Table 2: List of States in Nigeria with some of their attractions

\begin{tabular}{|c|c|c|c|}
\hline S/NO & STATE & ATTRACTIONS & DESCRIPTION \\
\hline \multirow[t]{6}{*}{1} & Abia & Arochukwu Caves & Natural Attraction \\
\hline & & National War Museum Umuahia \& Museum of Colonial History Aba & $\begin{array}{l}\text { Historic/Man-made } \\
\text { Attraction }\end{array}$ \\
\hline & & Akwette Weaving Centre Arts and Crafts (Souvenirs) & Cultural Attraction \\
\hline & & Long juju of Arochukwu Cultural festivals & Cultural Attraction \\
\hline & & Azumini Blue River & Natural Atraction \\
\hline & & Museum of Colonial History Monument & Man-Made/Historic \\
\hline \multirow[t]{6}{*}{2} & Adamawa & Gashaka Gumti National Park & Natural Attraction \\
\hline & & Sukur (UNESCO World Monument Heritage Site) & $\begin{array}{l}\text { Man-made/cultural } \\
\text { Attraction }\end{array}$ \\
\hline & & Lamurde Hot Spring & Natural Attraction \\
\hline & & Modibbo Adam's Tomb Monument & Man-made Attraction \\
\hline & & Three Sister Rocks Monument and Mandara Mountains & Natural Attractions \\
\hline & & Kiri Dam & Natural Attraction \\
\hline \multirow[t]{5}{*}{3} & AkwaIbom & Ibeno Sand Beach & Natural Attraction \\
\hline & & IBOM Mobil oil treatment & Man-made Attraction \\
\hline & & Ekpo Masquerade festival & Cultural Attraction \\
\hline & & Oron Museum/ Monument & Man-made Attraction \\
\hline & & Mary Slessor House/ Monument Tomb & Historic Attraction \\
\hline \multirow[t]{10}{*}{4} & Anambra & Ogbunike Caves & Natural Attraction \\
\hline & & Rojeny Tourist Village & Man-made Attraction \\
\hline & & Agulu lake/Gully & Natural Attraction \\
\hline & & Aguleri Game Reserve & Natural Attraction \\
\hline & & Igbo Ukwu Archaeological Monuments Reservations & Historic Attraction \\
\hline & & Egwu-imo-awka festival & Cultural Attraction \\
\hline & & Owerre-ezukalla cave & Natural Attraction \\
\hline & & Ajalli cave & Historic Attraction \\
\hline & & Ufuma cave & Historic Attraction \\
\hline & & New Yam Festival & Cultural Attraction \\
\hline \multirow[t]{4}{*}{5} & Bauchi & Balewa Tomb & Man-made Attraction \\
\hline & & Lame/Bura Game Reserve & Natural Attraction \\
\hline & & Geji Rock Painting & Historic Attraction \\
\hline & & Yankari National Park & Natural Attraction \\
\hline \multirow[t]{4}{*}{6} & Bayelsa & Oloibiri Oil Museum & Historic Attraction \\
\hline & & Slale Transit Hall Resort & Man-made Attraction \\
\hline & & Igidi Shrine & Cultural Attraction \\
\hline & & Kolo Creek & Natural Attraction \\
\hline \multirow[t]{8}{*}{7} & Benue & Ushongo Hills & Natural Attraction \\
\hline & & Ikwe Holiday Resort & Man-made Attraction \\
\hline & & Enemabia Warm Spring & Natural Attraction \\
\hline & & Kwag-hir Puppet Festival & Cultural Attraction \\
\hline & & Dajo Pottery, Makurdi Traditional TIV Anger Weavers Monument Ajikpo & Cultural Attraction \\
\hline & & J.S. Tarka Foundation Cultural Centre Makurdi & Man-made Attraction \\
\hline & & Montane Game Reserve & Natural Attraction \\
\hline & & Katsina-Ala River & Natural Attraction \\
\hline \multirow[t]{6}{*}{8} & Borno & Laffy falls & Natural Attraction \\
\hline & & Chad Basin National Park & Natural Attraction \\
\hline & & Abba Kari Zoo & Natural Attraction \\
\hline & & Gwoza Hills Natural & Natural Attraction \\
\hline & & Sambisa Game Reserve & Natural Attraction \\
\hline & & Kyarimi Amusement Resort & Man-made Attraction \\
\hline \multirow[t]{4}{*}{9} & Cross River & Kwa falls & Natural Attraction \\
\hline & & Agbokim falls & Natural Attraction \\
\hline & & Obudu Cattle Ranch Resort & Man-made Attraction \\
\hline & & Cross River National Park & Natural Attraction \\
\hline
\end{tabular}




\begin{tabular}{|c|c|c|c|}
\hline & & Ekpe Masquerade & Cultural Attraction \\
\hline & & National Museum and Monuments & Man-made Attractions \\
\hline & & Slave history museum & Man-made Attractions \\
\hline & & Old residency museum & Man-made Attractions \\
\hline & & Tinapa & Man-made Attractions \\
\hline & & Marina Resort & Man-made Attractions \\
\hline \multirow[t]{3}{*}{10} & Delta & Chief Nana's Palace & Cultural Attraction \\
\hline & & Ethiope River & Natural Attraction \\
\hline & & Escravo's Beach & Natural Attraction \\
\hline \multirow[t]{3}{*}{11} & Ebonyi & Umuana Afikpo Golden Natural Lake Sand Beach & Natural Attraction \\
\hline & & Quarry Sites & Man-made Attraction \\
\hline & & Salt mining site in Ubulu & Man-made Attraction \\
\hline \multirow[t]{8}{*}{12} & Edo & Fugar Caves & Natural Attraction \\
\hline & & Okomu Wildlife Eco-Tourism Sanctuary & Natural Attraction \\
\hline & & Igun Bronze Casting, & Cultural Attraction \\
\hline & & Oba's Palace, Benin & Cultural Attraction \\
\hline & & Ramat Park & Man-made Attraction \\
\hline & & Sakpoba Holiday Resort & Man-made Attraction \\
\hline & & Asoro Shrine & Cultural Attraction \\
\hline & & Samorikal Hills & Natural Attraction \\
\hline \multirow[t]{3}{*}{13} & Ekiti & Erinta Falls & Natural Attraction \\
\hline & & Olosunta Hills & Natural Attraction \\
\hline & & Ikogosi, Warm Spring & Natural Attraction \\
\hline \multirow[t]{8}{*}{14} & Enugu & Mmanwu Festival & Cultural Attraction \\
\hline & & Nike Holiday Resort & Man-made Attraction \\
\hline & & Ezeagu Tourist Complex & Man-made Attraction \\
\hline & & Nkalagu Silicon Sand & Man-made Attraction \\
\hline & & Iva Valley Coal Mine & Natural-made Attraction \\
\hline & & Iheneke Lake & Natural Attraction \\
\hline & & Ezeagu Cave & Natural Attraction \\
\hline & & Museum of National Unity & Man-made Attraction \\
\hline \multirow[t]{10}{*}{15} & FCT & Abuja Amusement Park, & Man-made Attraction \\
\hline & & Abuja Gardens & Man-Made Attraction \\
\hline & & Abuja Zoological Garden and Zoo & Man-made Attraction \\
\hline & & ECOWAS Secretariat Man-made & Man-made Attraction \\
\hline & & Women Development Resort & Man-made Attraction \\
\hline & & Abuja Plant Nursery & Man-made Attraction \\
\hline & & Aso Rock & Man-made Attraction \\
\hline & & Usman Dam & Man-made Attraction \\
\hline & & IBB Golf Course Sports & Man-made Attraction \\
\hline & & Jabi Dam & Man-made Attraction \\
\hline \multirow[t]{4}{*}{16} & Gombe & Tula Highlands/Hills Physical & Natural Attraction \\
\hline & & The Famous Tangale Dome Shaped Rock/Hill Formation & Natural Attraction \\
\hline & & Dadin Kowa Dam/Tomatoes Factory \& Farms & Man-made Attraction \\
\hline & & Buba Yero Tomb & Man-made Attraction \\
\hline \multirow[t]{7}{*}{17} & Imo & Oguta Lake & Natural Attraction \\
\hline & & Ikeji Festival & Cultural Attraction \\
\hline & & Palm Beach Holiday Resort, Ibawari-Ogwa village & Man-made Attraction \\
\hline & & Zoological and Botanical Garden & Natural Attraction \\
\hline & & Mbari-cultural center & Man-made Attraction \\
\hline & & Amusement Park & Man-made Attraction \\
\hline & & Owerri Zoo & Man-made Attraction \\
\hline \multirow[t]{4}{*}{18} & Jigawa & Hadejia/Ngum Wetlands and Bird Sanctuary & Natural Attraction \\
\hline & & Ringim Dyeing Pits & Cultural Attraction \\
\hline & & Baturiya Birds Sanctuary Wildlife & Natural Attraction \\
\hline & & Wowan Rafi Lake & Natural Attraction \\
\hline \multirow[t]{6}{*}{19} & Kaduna & Luggard Hall and Government Monument Bridge & Historic Attraction \\
\hline & & General Hassan Usman Park & Man-made Attraction \\
\hline & & Nok Terra Cotta, Nok Village & Cultural Attraction \\
\hline & & National Museum & Man-made Attraction \\
\hline & & Emir of Zazzau's Palace & Cultural Attraction \\
\hline & & Jakaranda Pottery & Man-made Attraction \\
\hline \multirow[t]{7}{*}{20} & Kano & Roxy Amusement Park, Cooky Amusement Park Kano & Man-made Attraction \\
\hline & & Hills and Valleys Amusement Park Dawakin Kudu Junction & Man-made Attraction \\
\hline & & Bagauda Lake/Tiga Lake Resort & Man-made Attraction \\
\hline & & Audu Bako Zoo & Man-made Attraction \\
\hline & & Durbar & Cultural Attraction \\
\hline & & Gidan Makama Museum & Man-made Attraction \\
\hline & & Emir of Kano's Palace & Cultural Attraction \\
\hline
\end{tabular}




\begin{tabular}{|c|c|c|c|}
\hline & & Kofar Mata Dyeing Pit & Cultural Attraction \\
\hline & & Bagauda Lake Resort Conference Centre & Man-Made Attraction \\
\hline \multirow[t]{5}{*}{21} & Katsina & 300 years old Gobarau Minaret & Cultural Attraction \\
\hline & & Emir of Katsina Palace & Cultural Attraction \\
\hline & & 10th Century Kusugu Well & Cultural Attraction \\
\hline & & 11th Century KASTINA City Walls of 7 gates & Historic Attraction \\
\hline & & Jibia Holiday Resort & Man-made Attraction \\
\hline \multirow[t]{7}{*}{22} & Kebbi & Argungu Fishing Festival & Cultural Attraction \\
\hline & & Kanta Museum (Monument) & Man-made Attraction \\
\hline & & Girmace Shrine in Zuru & Cultural Attraction \\
\hline & & Emir of Gwandu's Palace & Cultural Attraction \\
\hline & & Emir of Argungu's palace & Cultural Attraction \\
\hline & & Emir of Zuru's palace & Cultural Attraction \\
\hline & & Rima River & Natural Attraction \\
\hline \multirow[t]{8}{*}{23} & Kogi & Ata Igala's Palace & Cultural Attraction \\
\hline & & Inikpi (Shrine) Statue (Monument) & Cultural Attraction \\
\hline & & Kpata Rock & Natural Attraction \\
\hline & & Confluence Zone (River Niger and River Benue intercession) & Natural Attraction \\
\hline & & Confluence Hotel & Man-made Attraction \\
\hline & & Relics of Colonial History & Historic Attraction \\
\hline & & Lord Luggard's Residence \& Office & Historic Attraction \\
\hline & & Iron of Liberty Monument & Man-made Attraction \\
\hline \multirow[t]{4}{*}{24} & Kwara & Owu Water Falls & Natural Attraction \\
\hline & & Wreckage of Mungo Park Boat (Monument) & Historic Attraction \\
\hline & & Owe Kajita Falls and Owu Water Falls & Natural Attraction \\
\hline & & Ubo Aiyegunle Lake & Natural Attraction \\
\hline \multirow[t]{9}{*}{25} & Lagos & $\begin{array}{l}\text { Bar Beach, Badagry Beach, Kaiyetoro Maiyegun Beach, Eleko Beach, } \\
\text { Lekki Peninsula. }\end{array}$ & Natural Attraction \\
\hline & & $\begin{array}{l}\text { Apapa Amusement Park, } \\
\text { Frankid Leisure Park, Festac Resort }\end{array}$ & Man-made Attraction \\
\hline & & Lekki Conservation Centre & Man-made Attraction \\
\hline & & National Museum, Onikan Museum & Man-made Attraction \\
\hline & & Slave Relics (Monument) & Historic Attraction \\
\hline & & First Storey Building (Monument) & Historic Attraction \\
\hline & & MUSON Centre, and National Theatre & Man-made Attraction \\
\hline & & Oba's Palace & Cultural Attraction \\
\hline & & Eyo Festival & Cultural Attraction \\
\hline \multirow[t]{9}{*}{26} & Nassarawa & Peperuwa Lake & Natural Attraction \\
\hline & & Late Captain Maloney Tomb & Man-made Attraction \\
\hline & & Ogan Fishing and Cultural Festival & Cultural Attraction \\
\hline & & Akiri Warm Spring with Curative Power & Natural Attraction \\
\hline & & Dyeing Pits and Calabash Carving in Lafia & Cultural Attraction \\
\hline & & Farin Ruwa Falls Wildlife/Eco-Tourism & Natural Attraction \\
\hline & & Numan Rocks & Natural Attraction \\
\hline & & Eggon Hills and Caves & Natural Attraction \\
\hline & & Keffi Hunting (competiton) & Cultural Attraction \\
\hline \multirow[t]{6}{*}{27} & Niger & Gurara Falls & Natural Attraction \\
\hline & & Zuma Rock & Natural Attraction \\
\hline & & Kainji Lake National Park Wildlife & Natural Attraction \\
\hline & & Brass/Glass Works in Bida & Cultural Attraction \\
\hline & & Shirro Dam Tourist Resort & $\begin{array}{l}\text { Natural/Man-made } \\
\text { Attraction }\end{array}$ \\
\hline & & Mayanka Water Falls & Natural Attraction \\
\hline \multirow[t]{6}{*}{28} & Ogun & Adire Market & Cultural Attraction \\
\hline & & Olumo Rock & Natural Attraction \\
\hline & & Birikisu Sungbo Shrine & Cultural Attraction \\
\hline & & Obute-Oni Tourist Beach & Natural Attraction \\
\hline & & Alake of Egbaland (Monument) & Historic Attraction \\
\hline & & Ogunde Theatre Centre (Monument) & Man-made Attraction \\
\hline \multirow[t]{3}{*}{29} & Ondo & Idanre Hills & Natural Attraction \\
\hline & & Ipale Iloro Water Fall & Natural Attraction \\
\hline & & Owo Museum & Man-made Attraction \\
\hline \multirow[t]{4}{*}{30} & Osun & Mat Weaving & Cultural Attraction \\
\hline & & Ooni's Palace & Cultural Attraction \\
\hline & & Osun Osogbo Festival & Cultural Attraction \\
\hline & & Obafemi Awolowo University & Cultural Attraction \\
\hline \multirow[t]{4}{*}{31} & Oyo & Igbeti Hills & Natural Attraction \\
\hline & & Trans Amusement Park & Man-made Attraction \\
\hline & & Captain Bower, Tower(Monument) & Man-Made Attraction \\
\hline & & Agodi Gardens & Man-made Attraction \\
\hline
\end{tabular}


Designing and Developing a Gis Database For Tourism In Nigeria: The Case Of Anambra State

\begin{tabular}{|c|c|c|c|}
\hline & & Old Oyo National Park & Natural Attraction \\
\hline & & University of Ibadan Zoo/ Zoological Garden & Man-made Attraction \\
\hline & & Alaafin of Oyo's Palace & Cultural Attraction \\
\hline & & Calabash Carving & Cultural Attraction \\
\hline & & Ado-Awage Suspended Lake & Natural Attraction \\
\hline & & Aso Oke Weaving & Cultural Attraction \\
\hline \multirow[t]{9}{*}{32} & Plateau & Assop Falls & Natural Attraction \\
\hline & & Shere Hills & Natural Attraction \\
\hline & & International Youth Tourism Centre & Man-made Attraction \\
\hline & & Rayfield Resort & Man-made Attraction \\
\hline & & Jos Wildlife Park & $\begin{array}{l}\text { Natural Attraction/Man- } \\
\text { made }\end{array}$ \\
\hline & & Jos Zoo & Man-made Attraction \\
\hline & & MONTANA Museum & Man-made Attraction \\
\hline & & Naraguta Leather Works, Arts \& Crafts & $\begin{array}{l}\text { Man-made/Cultural } \\
\text { Attraction }\end{array}$ \\
\hline & & Solomon Lar Amusement Park & Man-made Attraction \\
\hline \multirow[t]{4}{*}{33} & Rivers & Monument of King Jaja of Opobo & Man-made Attraction \\
\hline & & Okrika Aquatic Stadium & Man-made Attraction \\
\hline & & Ifoko Beach & Natural Attraction \\
\hline & & Port Harcourt Tourist Beach & Natural Attraction \\
\hline \multirow[t]{3}{*}{34} & Sokoto & Tomb of Usman Dan Fodio & Man-made Attraction \\
\hline & & Sultan's Palace & Cultural Attraction \\
\hline & & Sokoto Museum & Man-made Attraction \\
\hline \multirow[t]{3}{*}{35} & Taraba & Mambilla Holiday Resort & Man-made Attraction \\
\hline & & Gashaka Gumti National Park & Natural Attraction \\
\hline & & Kpambo and Fikiyu Mysterious Rocks & Natural Attraction \\
\hline \multirow[t]{5}{*}{36} & Yobe & Dufuna Canoe & Historic Attraction \\
\hline & & Nguru Bird Life Project & Natural Attraction \\
\hline & & Gujba Forest Reserve Wildlife & Natural Attraction \\
\hline & & Fika Ancient Town & Historic Attraction \\
\hline & & Mai Madrinama's Palace & Cultural Attraction \\
\hline \multirow[t]{4}{*}{37} & Zamfara & Kuyambana Game Reserve & Natural Attraction \\
\hline & & Dashi tunnel & Natural Attraction \\
\hline & & Kiyawa city wall & Historic Attraction \\
\hline & & Bakolori dam & Man-made Attraction \\
\hline
\end{tabular}

Source: Adapted from Nigeria First National Biodiversity Report 2001) 